Revista do SELL

v. $4, n^{\circ} .1$

ISSN: $1983-3873$

\title{
O CRISTO DE HANS HOLBEIN NA COMPOSIÇÃO INTERNA DA OBRA O IDIOTA, DE DOSTOIÉVSKI
}

\author{
HANS HOLBEIN'S CHRIST IN THE INNER COMPOSITION OF DOSTOEVSKY'S THE \\ IDIOT
}

Христос Ганса Гольбейна в внутрненной композиции произведения Идиот Достоевского

Priscila Rodrigues von Glehn
Universidade de Brasília

\begin{abstract}
RESUMO: Um Cristo morto que traz em todo o seu semblante a dor e o sofrimento, um cadáver rígido que traz as marcas do tormento e da putrefação, um Cristo homem despido de sua divindade; foi esse Cristo que tanto impressionou Dostoiévski, tendo sido retratado em um de seus romances mais íntimos e pessoais, em que há um entrelaçamento de todas as suas convicções e apresenta, em sua tessitura, o ideal de perfeição e beleza. A partir do estudo do romance O idiota (1868), de Fiódor Mikhailovitch Dostoiévski e do quadro $O$ corpo de Cristo morto na tumba (1521), do pintor alemão renascentista Hans Holbein, o jovem, este trabalho analisa o ponto de vista interno na estrutura composicional do romance, ao levar em consideração a semiótica russa dos teóricos Boris Uspênski e luri M. Lotman. Este trabalho procura demonstrar como a influência do quadro no autor pessoa é elaborada pelo autor criador (termos definidos por Mikhail Bakhtin) no romance. O trabalho procura, nesse sentido, demonstrar a influência do quadro no autor pessoa, no que concerne à criação da obra $O$ idiota. Por meio da fala de seus personagens (príncipe Míchkin, Rogójin e lppolit), exteriorizam-se os sentimentos que emergiram em Dostoiévski quando, pela primeira vez, viu o quadro $O$ corpo de Cristo morto na tumba.
\end{abstract}

PALAVRAS-CHAVE: Dostoiévski; semiótica; Holbein; Cristo.

ABSTRACT: A dead Christ who brings across his face pain and suffering, a rigid corpse that bears the marks of agony and putrefaction, a human Christ stripped of his divinity; that Christ impressed Dostoevsky so much, and it was portrayed in one of his more intimate and personal novels, which bears an interweaving of all his convictions and presents and presents the ideal of perfection and beauty. Based on the study of the novel The idiot (1868), by Fyodor Mikhailovich Dostoevsky, and the picture The body of the dead Christ in the tomb (1521), by Renaissande German painter Hans Holbein, the younger, this paper analyzes the internal point of view in the compositional structure of the novel, considering the Semiotics of Russian theorists Boris Uspensky and Youri Lotman. This paper seeks to demonstrate how the influence of the picture on the author-person is elaborated by the author-creator (as defined by Mikhail Bakhtin) in the novel The idiot. By the discourse of its characters (Prince Myshkin, Rogozhin and Ippolit), the feelings that emerged in Dostoevsky when he first saw the picture The body of the dead Christ in the Tomb are manifested.

KEYWORDS: Dostoevsky; semiotics; Holbein; Christ. 


\section{Revista do SELL}

v. $4, n^{\circ} .1$

ISSN: $1983-3873$

Резюме: Мёртвый Христос в лице которого показано боль, горе и страдание, мёртвый труп в следах которых мучение и гниение. Христос человек совсем голый без его божественности Христа. Именно этот Христос произвел на Достоевского глубокое впечатление поэтому прекрасно изображал его в одной из найболее интимных, личных своих романов, в котором автор показывает чередования всех его убеждений и представления о идеальной красоте и совершенства. Начиная изучение и исследование произведения Идиот (1868) великого писателя Фёодора Михайловича Достоевского и художественной картины известного немецкого художника периода возрождения Ганса Гольбейна Мертыый Христос в гробу (1521), мы хотим анализировать внутренную точку зрения, композий и структуры романа, имея в виду русскую семиотику знаменитых теоретиков Б. А. Успенского и Ю. М. Лотмана. Таким образом, мы постараемся продемонстрировать влияние картины на автора - человека в его романе Идиот, влияние которого также отражено в самого автора - создателя. Через голоса их персонажей (принц Мышким, Рогохин и Иполит) показываются чувства Достоевского когда в первый раз увидел и посмотрел эту картину.

Ключевые слова: Достоевский; семиотика; Гольбейн; Христос.

\section{Introdução}

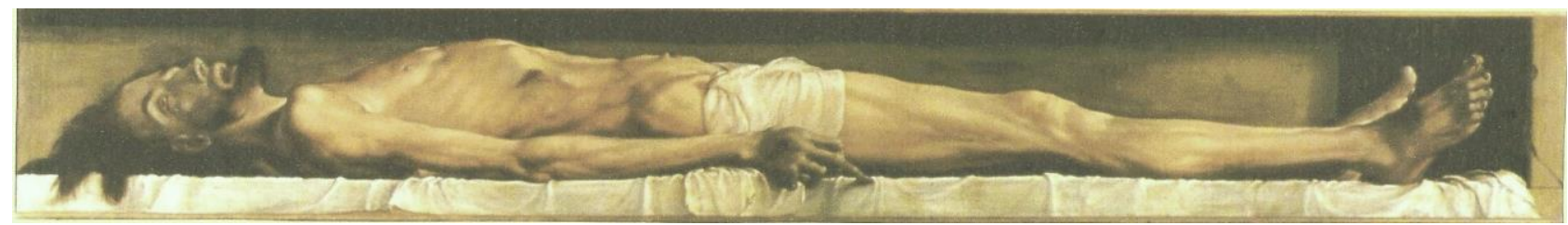

Duas obras separadas pelo tempo e ligadas pela criação artística: Hans Holbein, em 1521, criava o seu Cristo, um quadro que choca por seu realismo e pela impotência de seus espectadores diante da morte crística. Em 1868, Dostoiévski publicava as primeiras páginas de seu romance $O$ idiota.

São 347 anos que as separam e, ao mesmo tempo, as unem, uma vez que Dostoiévski, ao ver esse quadro, ficou profundamente impressionado, e essa impressão se refletiu no romance citado. Mas que elementos as unem? Qual a importância do quadro na estrutura composicional do romance? Que elementos do romance permitem uma análise centrada no quadro? Será que podemos dizer que o autor pessoa no romance em questão sobressai em relação ao autor criador?

Para desenvolver alguma discussão acerca desses questionamentos, é pertinente buscar na semiótica russa, especificamente na teoria do ponto de vista interno na narração, desenvolvida pelos teóricos russos luri M. Lotman e Boris A. Uspênski, 


\section{Revista do SELL}

v. $4, n^{\circ} .1$

ISSN: $1983-3873$

elementos que atestam a influência do quadro no autor pessoa, no que tange à criação da obra O idiota.

Para Lotman (1978), a relação entre o ponto de vista e o texto literário será sempre a analogia criador/criação. Para ele, quando a teoria do ponto de vista interno é aplicada ao texto literário, trata-se do problema da posição do autor do herói aplicada ao modelo de cultura que, por sua vez, estão relacionadas às questões filosóficas em geral, com ênfase à origem do mundo e à sua racionalidade.

Uspênski (1979), ao abordar a diversidade dos pontos de vista na pintura e na literatura, considerará dois pontos de vista: o interno e o externo. No primeiro caso, o autor criador, quando adota uma posição externa, descreverá os acontecimentos de fora, ou seja, ele apenas reporta uma ação sem se colocar na posição de participante direto dos acontecimentos. Já no ponto de vista interno, objeto da investigação, o autor pode situar-se em alguma posição interna no que tange à narrativa, em que ele pode assumir o ponto de vista de um ou outro participante em relação aos acontecimentos narrados ou ocupar a posição de uma pessoa que se encontra no lugar da ação, sem nela tomar parte.

Nesses termos, ao abordar o posicionamento da relação criador/criação, não se pretende reduzir a obra dostoievskiana a um mero trabalho de análise autobiográfica; porém, Dostoiévski talvez seja um dos poucos escritores cuja complexidade da obra só pode ser entendida a partir do conhecimento prévio do autor pessoa. Podemos dizer que Dostoiévski é um autor atípico, porque em suas obras podemos vislumbrá-lo enquanto pessoa refletida em cada página. Essa característica é mais marcante nas obras da maturidade, mas elementos autobiográficos podem ser percebidos em suas obras pósSibéria.

Embora o autor insira elementos autobiográficos em seus romances, isso não significa que suas personagens são meros fantoches produzidos pela sua pena. Pelo contrário, Dostoiévski, considerado o criador do romance polifônico por Mikhail Bakhtin (2008), cria seres livres e autônomos que dialogam em pé de igualdade com o seu criador.

II. O Cristo humano de Hans Holbein

"Ora, por causa desse quadro pode-se perder a fé."

Dostoiévski (1867). 


\section{Revista do SELL}

v. $4, n^{\circ} .1$

ISSN: $1983-3873$

O pintor renascentista alemão Hans Holbein, o moço, nasceu em Augsburg no ano de 1497 e morreu em Londres, em 1543. Hans Holbein não é um pintor popular como Leonardo da Vinci, Michelangelo e tantos outros; todavia, foi o criador do Cristo mais humano, perturbador e enigmático de toda a história da pintura.

Holbein foi, sobretudo, um grande retratista e um notável gravador. Inicialmente influenciado pelas técnicas renascentistas, logo desenvolveu o próprio estilo. Suas obras são realistas e precisas, dando atenção a cada detalhe.

Em 1521, Holbein pintou O corpo de Cristo morto na tumba, exposto desde sua criação até os dias atuais no Museu de Basileia. O quadro representa apenas um cadáver deitado num pedestal coberto com um lençol branco desalinhado. Os únicos elementos que confirmam se tratar do Cristo são os estigmas da crucificação.

Kristeva faz uma descrição muito pertinente do quadro em sua obra Sol negro:

[...] de tamanho humano, este cadáver pintado é representado de perfil, com a cabeça ligeiramente inclinada para o espectador, os cabelos espalhados sobre o lençol. O braço direito, visível, acompanha o corpo descarnado e torturado e a mão ultrapassa ligeiramente o pedestal. O peito saltado esboça um triângulo no interior do retângulo muito baixo e alongado do nicho que constitui o plano do quadro. Esse peito apresenta o traço sangrento de uma lança, e na mão veem-se os estigmas da crucificação que endurecem o dedo médio esticado. Os traços dos pregos marcam os pés do Cristo. O rosto do mártir traz a expressão de uma dor sem esperança, o olhar vazio, o perfil aguçado, a tez verde azulada são os de um homem realmente morto, do Cristo abandonado pelo pai ("Pai, por que me abandonastes") e sem promessa de Ressurreição (KRISTEVA, 1989, p. 105).

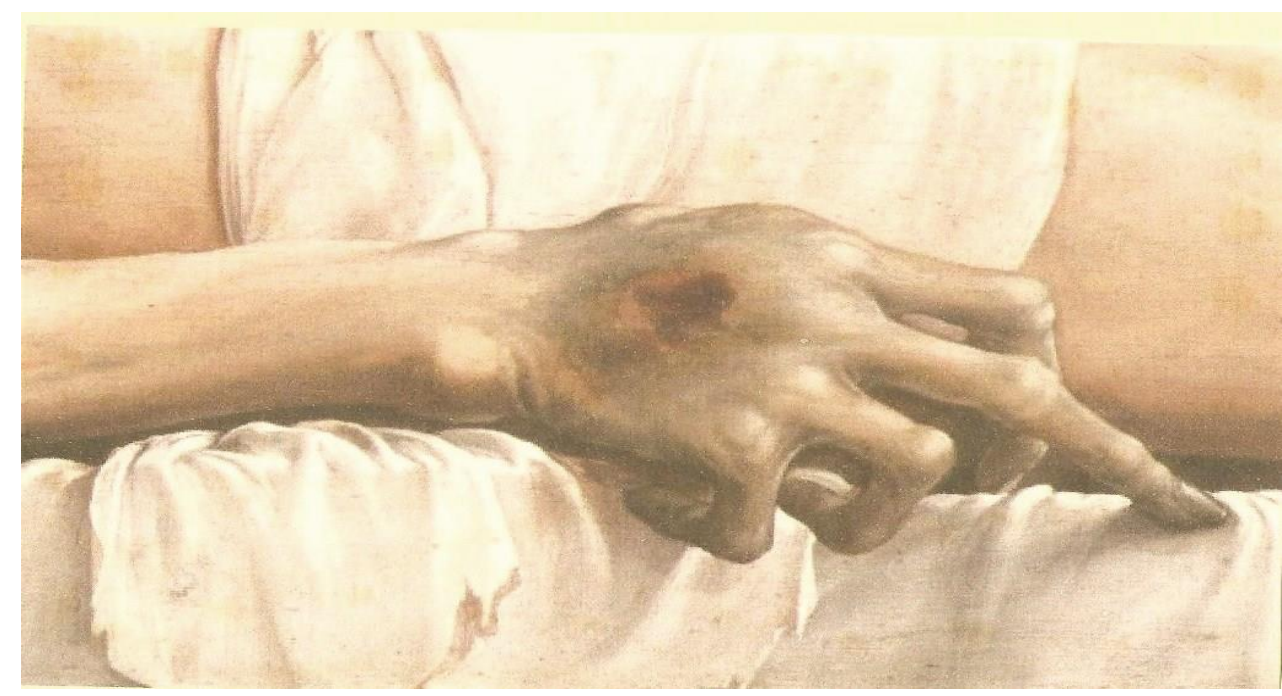




\section{Revista do SELL}

v. $4, n^{\circ} .1$

ISSN: $1983-3873$

O Cristo de Hans Holbein não traz a representação de um ser divino, um Deus salvador, mas um homem realmente morto, um Cristo abandonado e sem promessa de ressurreição. Diante disso, Holbein omite qualquer embelezamento divino nessa obra e apenas enfatiza uma morte definitiva; por conseguinte, única impressão que o quadro transmite ao espectador estarrecido é de que esse Cristo não ressuscitará. Como afirma Kristeva (1989, p. 105), "[...] esse cadáver não se levantará mais".

De fato, o Cristo representado por Holbein tanto impressionou Dostoiévski. Um Cristo que traz em seu semblante a dor e o sofrimento, um cadáver rígido que apresenta as marcas do sofrimento e da putrefação; enfim, um Cristo homem despido de sua divindade.

O encontro de Dostoiévski com o Cristo de Holbein aconteceu no ano de 1867, em Genebra, durante o período em que morou na Europa. Na obra Meu marido Dostoiévski, Ana Grigorievna Dostoievskaia, segunda esposa do autor, faz um relato preciso do momento em que o autor ficou frente a frente com o quadro:

Este quadro de Hans Holbein retratava Jesus Cristo após suportar torturas desumanas, retirado da cruz e em estado de decomposição. Seu rosto inchado estava coberto de feridas sangrentas, sua aparência era horrível. O quadro deprimiu Fiodor Mikhailovitch, que se sentiu derrotado diante dele. Eu não tive forças para olhar o quadro, me impressionava com facilidade, principalmente agora em meu estado delicado, e fui para outra sala. Quando voltei, quinze, vinte minutos depois, encontrei Fiódor Mikhailovitch ainda diante do quadro, como se estivesse preso. A expressão de seu rosto era de preocupação e susto, a mesma que vi, várias vezes, nos primeiros minutos de um ataque de epilepsia. Devagarzinho, peguei meu marido pela mão, levei-o para outra sala e me sentei com ele num banco, esperando, a qualquer momento, o início da crise. Felizmente, isso não aconteceu: Fiódor Mikhailovitch, aos poucos, se acalmou e, quando saímos do museu, insistiu em voltar mais uma vez para ver o quadro que tanto o impressionou (DOSTOIEVSKAIA, 1999, p. 133). 


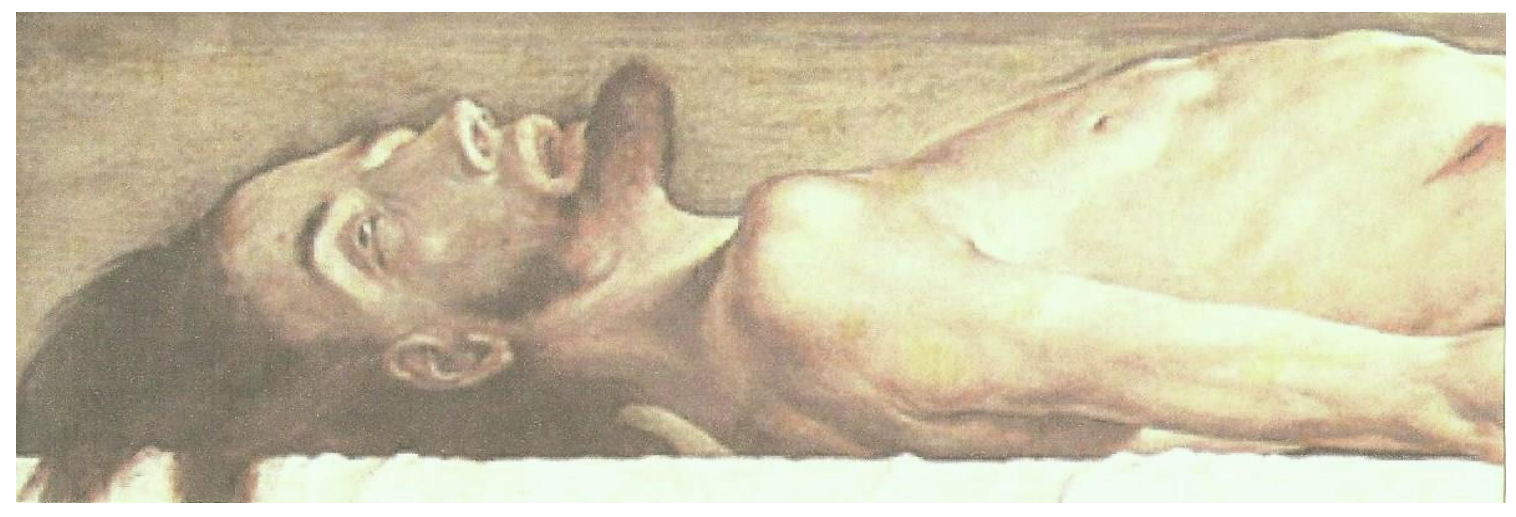

Dostoiévski, ao olhar para esse quadro, viu, nas pinceladas precisas de Holbein, a junção de todos os seus anseios. Além disso, a representação do seu ideal e beleza que estava na figura do Cristo homem, o sofrimento da humanidade, a descrença e a compaixão (FRANK, 2008).

III. Príncipe Míchkin - o Cristo humano de Dostoiévski

O romance $O$ idiota, publicado em 1868, foi gerado num momento em que Dostoiévski passava por um período bem conturbado em sua vida: o sofrimento de viver longe de sua amada pátria, a falta constante de dinheiro, a pressão para terminar o romance em tempo hábil e o pior de tudo, a morte de sua primeira filha, com poucos meses de vida.

Tal obra é considerada, por alguns estudiosos (FRANK, 2003; GROSSMAN, 1967), como a mais íntima e pessoal do escritor russo. O leitor que possui certa intimidade com a obra dostoievskiana percebe de imediato a presença do autor pessoa na criação do autor criador. Apenas na obra $O$ idiota o autor expõe a angústia que sentiu diante do pelotão de fuzilamento e dos poucos minutos de vida lhe que restavam.

[...] no entanto, embora $O$ idiota seja o mais desigual dos quatro melhores romances de Dostoiévski, é o único em que sua visão pessoal da vida, em toda a sua trágica complexidade, é expressa com a maior familiaridade, com a maior pungência e com um pathos lírico que raia a sublimidade (FRANK, 2003, p. 364).

A personagem central do romance $O$ idiota, o príncipe Míchkin, irá se diferenciar de todas as personagens do universo artístico dostoievskiano. É importante ressaltarmos que o príncipe foi criado a partir de três figuras que, ao longo da narrativa, podemos perceber de forma evidente: Dom Quixote, a criança e a figura de Cristo. 


\section{Revista do SELL}

v. $4, n^{\circ} .1$

ISSN: $1983-3873$

Ele é uma personagem que destoa das demais personagens de Dostoiévski. Primeiro, é um homem epilético, assim como o seu criador, e apresenta uma ingenuidade infantil que às vezes beira ao ridículo. Suas ações e atos remetem à figura do Cristo dos evangelhos, sendo que, ao contrário das outras personagens dostoievskianas, o príncipe Míchkin não vive uma ideia; ele é apenas uma representação de uma ideia do autor, que é a representação de um ser belo e perfeito.

Ao dar vida ao príncipe Míchkin, Dostoiévski coloca em prática um antigo desejo de criar um homem perfeitamente belo.

Já fazia tempo que eu tinha uma ideia me importunando, mas tinha medo de transformá-la num romance, porque era uma ideia muito difícil e eu não estava pronto para lidar com ela, embora fosse fascinante e eu tivesse me apaixonado por ela. A ideia é - retratar um homem perfeitamente belo. [...] A ideia costumava assomar de repente em minha mente de uma forma um pouco artística, mas somente um pouco, e não na forma totalmente desenvolvida como eu precisava. Foi somente a desesperada situação em que me encontrava que me fez aventurar-me numa ideia que ainda não estava totalmente madura. Aproveitei a chance, como na roleta: "Pode ser que se desenvolva à medida em que for escrevendo!". Isso é imperdoável (DOSTOIÉVSKI, 1868 apud FRANK, 2003, p. 359).

O romance $O$ idiota não foi a primeira tentativa de Dostoiévski em representar o homem belo, dado que ele trabalhou esse ideal, mas sem sucesso, em personagens no conto A aldeia de Stepántchikovo e seus habitantes (1859) e no romance Humilhados e ofendidos (1862). Embora a concepção e a caracterização do príncipe Míchkin sejam consideradas um triunfo artístico, e quase certamente o retrato mais marcante de uma personalidade cristã num romance realista, seu desempenho como uma encarnação das virtudes cristãs, um "homem positivamente belo", para usar a expressão do próprio Dostoiévski, permanece controversa, segundo alguns críticos que alegam o grande fracasso literário da obra dostoievskiana. Isso pode ser constatado nos escritos do teórico inglês John Jones, autor de Dostoiévski, importante trabalho sobre o autor russo publicado em 1983 (WILLIAMS, 2008).

Para tentar entender o significado da expressão um "homem positivamente belo", deve-se primeiramente compreender a famosa frase dostoievskiana - A beleza salvará o mundo (Красота спасёm мир ${ }^{1}$ ) - que, infelizmente, é utilizada de forma banalizada e fora do contexto em que foi formulada. Ela é pronunciada, pela primeira vez, pelo príncipe

\footnotetext{
Transliteração em alfabeto latino da frase: "Красота спасёm мир (Krasata spasiot mir)”.
} 


\section{Revista do SELL \\ v. $4, n^{\circ} .1$ \\ ISSN: $1983-3873$}

Míchkin na obra $O$ idiota e, depois, ressurge nos romances Os demônios e Os irmãos Karamázov.

Nesse entremeio, Bercken (2011) sugere que, para se ter uma imagem mais clara e coerente da ideia de beleza na concepção de Dostoievski, é preciso olhar para os seus artigos jornalísticos e, principalmente, para os cadernos de notas do autor.

A frase enigmática aparece no caderno de notas para $O$ idiota, porém com uma ligeira mudança em relação ao que se encontra no projeto final do romance: "O mundo será salvo pela beleza - dois tipos de beleza (Mup спасется красотой - два образчика $\left.к р а с о \mathrm{~m}^{2}{ }^{2}\right)$ ". Convém salientar que os dois tipos de beleza mencionados por Dostoiévski são o ético e o estético, ou seja, as belezas física e interior.

Para Dostoiévski, a beleza está ligada a um ideal ético, como é mencionado em seus documentos pessoais, de acordo com o teórico Bercken (2011). No romance não, aparece diretamente a relação entre beleza e ética, mas o príncipe Míchkin é a personificação da beleza moral. Esse príncipe demonstra uma força ética interna que cativa a todos, inclusive os que o chamam de idiota por causa de sua doença e, sobretudo, em razão de sua ingenuidade infantil. Ele é a personificação das virtudes evangélicas da mansidão, do perdão e da compaixão.

Numa carta à sua sobrinha, Sofia, Dostoiévski explica seu plano para o romance: ele quer retratar alguém com um ideal ético da beleza, "um homem positivamente belo" (положительно прекрасный человек ${ }^{3}$ ):

Há três semanas (dia 18 de dezembro), comecei um novo texto e agora trabalho noite e dia. A ideia do livro é antiga, mas sempre gostei muito dela; mas é muito difícil que até o momento eu não tenha criado coragem para levá-la adiante, e se retorno essa ideia é porque estou em uma situação desesperadora. A proposta básica é a representação de um homem verdadeiramente perfeito e nobre. $E$ isso é o mais difícil de encontrar que qualquer outra coisa neste mundo, particularmente em nossos dias. Todos os escritores, não somente os nossos, mas também os estrangeiros, que tentaram representar a Beleza Absoluta, foram desiguais em seus resultados, pois é algo infinitamente difícil de representar. A beleza é o ideal; mas ideais, seja entre nós ou na civilizada Europa, há muito se desfazem. Há no mundo apenas uma figura de absoluta beleza: Cristo. Aquela figura infinitamente adorável é, de fato, uma maravilha infinita (todo o Evangelho de São João está repleto desse pensamento; João vê a maravilha da Encarnação, a aparição visível do Belo) (DOSTOIÉVSKI, 2009, p. 138).

2 Transliteração em alfabeto latino da frase: "Мup спасется красотой - два образчика красоты (Mir spasioticia kracatoi - dva abraztchika)".

3 Transliteração em alfabeto latino da frase: “Положительно прекрасный человек (Polojitelina priekrasnii tcheloveka)". 


\section{Revista do SELL}

v. $4, n^{\circ} .1$

ISSN: $1983-3873$

Dostoiévski se refere a Cristo como a encarnação do "belo". O termo que o autor usa para a palavra "belo" em suas anotações é прекрасный", que é da mesma raiz de красивый sentido ético quanto estético. Nesse caso, pode-se inferir que Dostoiévski, ao utilizar o termo "belo", busca o sentido ético, na construção do príncipe Míchkin, que representaria o ideal cristão.

$\mathrm{Na}$ concepção do autor russo, somente Cristo poderia ser considerado um ser belo e perfeito. $O$ autor era um homem muito religioso, mas havia momentos em que era atormentado pela dúvida. Acreditava em Deus, mas Deus na sua concepção não representava a imagem ideal; Ele era um problema por tolher a liberdade humana. Enquanto isso, Cristo era a imagem ideal para Dostoiévski, mas não qualquer Cristo, e sim um Cristo homem.

[...] Quero dizer que nesses momentos, qual erva seca, devemos ter sede de fé, e que ao final a encontraremos, tão somente porque vemos mais claramente a verdade quando estamos infelizes. Confesso que sou uma criança mesmo com minha idade, uma criança da descrença e do ceticismo e provavelmente (no fundo, sei disso), serei assim até o fim da minha vida [...]. Deus me dá por vezes momentos de perfeita paz. Nesses momentos, tenho construído meu credo, no qual tudo é claro e sagrado para mim. Esse credo é extremamente simples: creio que não há nada mais adorável, profundo, compassivo, racional, viril e perfeito que o Salvador; digo a mim mesmo, com amor enciumado, que não só não há ninguém como Ele, mas que não poderia haver ninguém. Diria até mais: se alguém pudesse me provar que o Cristo está fora da Verdade, e se a verdade realmente excluísse o Cristo, eu preferiria estar com Cristo e não com a verdade (DOSTOIÉVSKI, 2009, p. 78).

Dostoiévski, como a maioria do povo russo, foi influenciado pela cristologia kenótica muito difundida no século XIX, na Rússia, também conhecida como a cristologia do esvaziamento. Berkouwer (1964) ressalta que a teologia da Kenosis apresenta um Cristo que, ao encarnar, teve de se despir total ou parcialmente de sua divindade e, ao passar por esse processo de esvaziamento, tornara-se homem. E o povo russo, obcecado pela humanidade de Cristo pregada pela cristologia kenótica, o venera não como um ser onipotente (pantocrata), mas como um homem (CLARK; HOLQUIST, 2008).

\footnotetext{
4 A palavra прекрасный (prekrasnyi) significa очень красивый (otchnie krasivyi), belo, lindo, formoso excelente (Dicionário Russo-Português, p. 475).

5 A palavra красивый (krasivyi) significa bonito, belo, lindo (Dicionário Russo-Português, p. 245).
} 


\title{
Revista do SELL \\ v. $4, n^{\circ} .1$ \\ ISSN: $1983-3873$
}

\begin{abstract}
Somente Cristo podia amar o homem como a si mesmo, mas Cristo era um ideal eterno permanente que o homem se esforça e, seguindo a lei da natureza, deveria esforçar-se para alcançar. Enquanto isso, desde o aparecimento de Cristo como ideal do homem na carne, tornou-se tão claro como o dia que o mais elevado desenvolvimento final da personalidade deve chegar a isso (ao próprio fim do desenvolvimento, à consecução final do objetivo) [...] (FRANK, 2002, p. 412).
\end{abstract}

Sendo assim, para Dostoiévski, Cristo era o portador do modelo da lei do amor, não o Cristo erguido que veio libertar a humanidade do terror e da morte. A única significação de Cristo, na forma como o autor russo acreditava, era servir como um enunciador da moral e do amor (FRANK, 2003).

\section{O entrelaçamento do Cristo de Holbein com o Cristo de Dostoiévski}

Красота спасёт мир.

Dostoiévski

No romance $O$ idiota, o quadro $O$ corpo de Cristo morto na tumba aparece apenas duas vezes ao longo das quase 700 páginas. O quadro tem um papel muito importante na estrutura composicional do romance, pois serve para o autor desenvolver suas questões políticas, filosóficas, religiosas e, nomeadamente, suas experiências pessoais.

Na primeira vez que o quadro aparece, o autor aborda a questão do ateísmo que começava a proliferar na Rússia entre a nova geração. O quadro é introduzido quase no meio do romance e pertence a Rogójin, uma personagem cuja fé está morrendo.

Um exemplo dessa luta do autor de externar tanto os sentimentos pessoais que ele sentiu ao ver o quadro, quanto o desejo de expor a crise religiosa da nova geração da Rússia, pode ser percebido no fragmento que reproduzimos abaixo:

Sobre a porta que dava para o cômodo seguinte havia um quadro bastante estranho pela forma, de aproximadamente dois archins e meio de comprimento e não mais de seis verchoks de altura. Um representava o Salvador recém-retirado da cruz. O príncipe olhou de relance para ele, como quem se lembra de alguma coisa, mas sem parar, queria passar em direção à porta. Estava sentindo um clima muito pesado e queria sair o mais depressa possível daquela casa. No entanto, Rogójin parou subitamente diante do quadro. - Veja todos esses quadros aqui - disse ele 


\section{Revista do SELL}

v. $4, n^{\circ} .1$

ISSN: $1983-3873$

-, todos foram rematados em leilões a um rublo ou dois pelo meu falecido pai, ele gostava disso. Um conhecedor os examinou todos aqui: porcaria, diz ele, mas este aqui - esse quadro acima da porta, também rematado por dois rublos -, diz ele, não é porcaria. Apareceu um e disse a meu pai que daria por ele trezentos e cinquenta rublos, mas Sviéliev, Ivan Dmítritch, um comerciante, grande apreciador, esse chegou a oferecer quatrocentos rublos, e na semana passada chegou a oferecer quinhentos ao meu irmão Semeon Semeónitch. Eu o reservei para mim. - Sim, mas isso... isso é uma cópia de Hans Holbein - disse o príncipe depois de observar o quadro -, embora eu não seja um grande conhecedor, parece-me uma cópia excelente. Eu vi esse quadro no exterior e não consigo esquecê-lo. - Ora... o que é que tu tens... Rogójin largou repentinamente o quadro e continuou seguindo em frente. É claro que a distração e o especial estado estranhamente irritadiço, que tão súbito se notou em Rogójin, poderia, talvez, explicar esse arrebatamento; mas ainda assim para o príncipe foi como que uma maravilha a interrupção tão súbita de uma conversa que ele mesmo não começara e a qual Rogójin sequer lhe respondera. - Então, Liev Nikolaitchik, há muito tempo eu queria te perguntar: tu acreditas ou não em Deus? - Rogójin retornou de repente a conversa depois de dar alguns passos. - Que estranho esse teu jeito de perguntar e... olhar! observou involuntariamente o príncipe. - É que eu gosto de olhar para esse quadro - murmurou Rogójin depois de uma pausa, como se estivesse esquecido mais uma vez a sua pergunta. - Para esse quadro! - exclamou num átimo o príncipe, sob a impressão de uma ideia repentina. - Para esse quadro! Ora, por causa desse quadro outra pessoa ainda pode perder a fé. - Vai acabar perdendo mesmo - reiterou de forma súbita e inesperada Rogójin. Os dois já haviam chegado à porta de saída (DOSTOIÉVSKI, 2002, p. 253-254).

Vemos por este fragmento do romance que a discussão a respeito da fé religiosa surge de um posicionamento do autor enquanto pessoa. Quando o príncipe diz: "Ora, por causa desse quadro outra pessoa ainda pode perder a fé [...]" (DOSTOIÉVSKI, 2002, p. 254) percebe-se que a personagem exterioriza o ponto de vista do autor, pois Dostoiévski, ao ver esse quadro, proferiu essas palavras diante da pintura.

No excerto seguinte Dostoiévski, através da pintura de Holbein, vai trabalhar uma questão muito importante dentro da concepção religiosa do autor. Para ele todo ser humano, para atingir o ideal de perfeição e beleza de Cristo, deveria sofrer, pois segundo o autor o homem só alcançaria esse ideal de perfeição quando seguisse o exemplo de Cristo que é o amor ao próximo, a humildade e o sacrifício.

Dostoiévski foi inicialmente muito criticado por sua concepção religiosa, e seus escritos rotulados como um "cristianismo rosa" por Konstantin Leontiev em 1880 ao escrever um artigo crítico abordando a visão religiosa do autor retratada em suas obras. Entretanto, Bercken (2011) ressalta que esse título dado ao cristianismo do autor não deve ser acolhido; pelo contrário, o cristianismo de Dostoiévski não tem nada de "rosa". 


\section{Revista do SELL}

v. $4, n^{\circ} .1$

ISSN: $1983-3873$

Ao pôr em prática os ensinamentos deixados por Cristo, como "amar o próximo" e principalmente "não julgar os outros", o exercício do cristianismo dostoievskiano torna-se uma tarefa humana quase impossível de se realizar. E Dostoiévski estava ciente desse fato, e o maior exemplo da impossibilidade de realizar esses preceitos evangélicos está na obra $O$ idiota, em que as personagens vivem em uma sociedade corrompida e gananciosa e não conseguem enxergar o ideal cristão na figura do Príncipe Míchkin, no qual veem apenas um "idiota". E o quadro de Holbein representa esse Cristo humilhado e sofredor que encarnou apenas para dar o exemplo a ser seguido pelos homens.

[...] Sim, sim! Não, Rogójin calunia a si mesmo; ele tem um coração imenso, tanto pode sofrer como ter compaixão. Quando vier a saber de toda a verdade e quando se convencer do quando é digno de pena esse ser prejudicado, meio louco - porventura ele não irá perdoá-la por tudo o que houve antes, por todos os seus sofrimentos? Porventura não se tornará seu servo, seu irmão, seu amigo, sua providencia? A compaixão irá compreender e ensinar ao próprio Rogójin. A compaixão é a lei mais importante e talvez a única da existência de toda a humanidade. [...] Esse homem deve sofrer intensamente. Ele diz que "gosto de olhar para esse quadro"; não gosta, mas quer dizer que sente necessidade. Rogójin não é só uma alma apaixonada; apesar de tudo, é um guerreiro: quer reaver pela força a sua fé perdida. Agora ela lhe é necessária a ponto de fazê-lo sofrer! É! Acreditar em alguma coisa! Acreditar em alguém! Veja mesmo assim, como é estranho aquele quadro de Holbein [...] (DOSTOIÉVSKI, 2002, p. 266).

No fragmento abaixo, referente ao romance, a personagem Hippolit, que pertence à geração niilista, analisa o quadro $O$ corpo de Cristo morto na tumba, partindo das possíveis reações dos espectadores diante do quadro. Ele vê o quadro como uma representação da derrota; a derrota da bondade pela eterna escuridão e da insensatez da humanidade. Um dos questionamentos dele ao final de sua análise é se a bondade encarnada na figura de Cristo pode viver efetivamente num mundo mecânico, de violência e de ausência de compaixão.

Quando eu me levantei para fechar a porta à chave às costas dele, de repente me veio à lembrança o quadro que eu virá há pouco em casa de Rogójin, sobre a porta de umas das salas mais escuras. Ele mesmo me mostrou de passagem esse quadro; parece que passei uns cinco minutos diante dele. Ali não havia nada de bom em termos de arte; mas o quadro me deixou numa intranquilidade estranha. O quadro era uma representação de Cristo recém-retirado da cruz. Acho que os pintores pegaram a mania de representar Cristo, seja na cruz, seja retirado da cruz, ainda com o matiz de uma beleza inusual no rosto; procuram conservar 


\section{Revista do SELL}

v. $4, n^{\circ} .1$

ISSN: $1983-3873$

essa beleza nele até durante os mais terríveis suplícios. No quadro de Rogójin não há uma só palavra sobre a beleza; ali está, na forma plena, o corpo de um homem que, ainda antes de ser levado à cruz, sofreu infinitos suplícios, ferimentos, torturas e espancamentos por parte da guarda, espancamento por parte do povo quando carregava a cruz nas costas e caiu debaixo dela e, por último, o suplício da cruz ao longo de seis horas (pelo menos de acordo com os meus cálculos). Na verdade, é o rosto de um homem que acaba de ser retirado da cruz, isto é, que conservou muita coisa viva, afetuosa; ainda não houvera tempo para enrijecer nada, de tal forma que no rosto do morto ainda aparecia o sofrimento, como se ele continuasse a senti-lo (o artista captou isso muito bem); mas, por outro lado, o rosto não foi minimamente poupado; ali está apenas a natureza, e em verdade assim deve ser o cadáver de um homem, seja lá quem for, depois de semelhantes suplícios. Eu sei que a igreja cristã já estabeleceu desde os primeiros séculos que Cristo não sofreu de maneira figurada, mas real e que, por conseguinte, o seu corpo na cruz foi subordinado à lei da natureza de forma plena e absoluta. No quadro esse rosto está horrivelmente fraturado pelos golpes, inchado, com equimoses terríveis, inchadas e ensanguentadas, os olhos abertos, as pupilas esguelhadas; as escleróticas graúdas e abertas irradiam um brilho mortiço, vítreo. Todavia, coisa estranha; quando se olha para esse cadáver do homem supliciado, surge uma pergunta especial e curiosa: se esse cadáver fosse visto exatamente assim (e sem falta ele devia ser exatamente assim) por todos os seus discípulos, por seus principais e futuros apóstolos, pelas mulheres que o seguiam e estavam ao pé da cruz, por todos os que nele acreditavam eu adoravam, estes, ao olharem para esse cadáver, como poderiam acreditar que esse mártir iria ressuscitar? Aí vem involuntariamente a ideia de que, se a morte é tão terrível e as leis da natureza são tão fortes, então como superá-las? Como superá-las se agora elas não foram vencidas nem por aquele que em vida vencia até a natureza, a quem esta se subordinava, aquele que exclamou: "Talita cumi" - e a menina se levantou, "Lázaro, vem para fora" - e o morto não saiu? Quando se olha esse quadro, a natureza nos aparece com a visão de um monstro imenso, implacável e surdo ou, mais certo, é bem mais certo dizer, mesmo sendo também estranho - na forma de alguma máquina gigantesca de construção moderna, que de modo absurdo agarrou, moeu e sorveu, de forma abafada e insensível, um ser grandioso e inestimável um ser que sozinho valia toda a natureza e todas as suas leis, toda a terra, que possivelmente fora criada unicamente para o aparecimento dele! É como se esse quadro exprimisse precisamente esse conceito de força obscura, insolente, absurda e eterna, à qual tudo está subordinado e é transmitido involuntariamente a você. Aquelas pessoas que rodeavam o morto, das quais não há nenhuma no quadro, devem ter experimentado uma terrível nostalgia e perturbação naquela noite que lhes devorou de uma vez todas as suas esperanças e quase todas as crenças. Todas devem ter-se afastado no mais terrível pavor, ainda que cada uma levasse consigo um pensamento imenso, que delas nunca mais poderia ser arrancado. E se aquele mesmo mestre pudesse ver a sua imagem na véspera da execução, teria ele próprio subido à cruz daquele jeito e morrido do jeito que agora se vê? Essa pergunta também nos passa involuntariamente pela cabeça quando se olha para esse quadro (DOSTOIÉVSKI, 2002, p. 455-458). 


\section{Revista do SELL \\ v. $4, n^{\circ} .1$ \\ ISSN: $1983-3873$}

O impacto da figura do Cristo de Holbein produziu em Dostoiévski um efeito devastador e consolador ao mesmo tempo. O Cristo de Holbein representava um grande desafio à fé de Dostoiévski no seu Cristo Deus homem, porque ali estava apenas um corpo humano torturado e definhado, cujo rosto não mostrava um único traço de beleza extraordinária com que se costuma pintar Cristo, mas apenas um Cristo que foi vencido pelas forças da natureza.

\section{Considerações Finais}

O intuito da análise do ponto de vista interno na estrutura composicional do romance $O$ idiota foi demonstrar a influência do quadro $O$ corpo de Cristo morto na tumba, de Holbein, no autor pessoa no momento da criação.

Dostoiévski, ao inserir no romance a pintura, tencionava não só transmitir para o leitor as sensações que o acometeram ao ver o quadro pela primeira vez, mas também introduzir e talvez desenvolver suas ideias cristocêntricas. A partir da pintura, o autor trabalha as questões do ateísmo que proliferava entre as novas gerações na Rússia; e apresenta uma sociedade corrompida pela ganância e, principalmente, pelo individualismo, pela ausência de compaixão pelo seu semelhante. Williams (2008) destaca que Dostoiévski relatou, muitos anos depois em seu Diário de um Escritor, que não havia atingido o seu objetivo, pois o romance não expressou um décimo do que ele tinha a intenção, mas que havia derramado as suas mais intensas experiências espirituais.

Desse modo, as análises comprovam a hipótese inicial de que o quadro serviu de leitmotiv para poder desenvolver, no romance, o posicionamento ideológico religioso do autor.

As duas obras se unem na temática de um Cristo humanizado. Uma apresenta o ideal de perfeição e beleza que estava na figura do Cristo humano idealizado pelo escritor russo, que é transposta para o romance na figura do príncipe Míchkin; e a outra possui a representação de um Cristo humanizado.

Outra questão relevante que devemos ressaltar é a importância da frase "A beleza salvará o mundo (Kрасота спасёm мир)", que, apesar de aparecer apenas duas vezes no romance, destaca, de forma condensada, todo o pensamento filosófico religioso do autor. Essa beleza que salvaria o mundo, mencionada pelo autor (muitas vezes interpretada erroneamente), não representa uma beleza física, mas a pessoa de Cristo. 


\section{Revista do SELL}

v. $4, n^{\circ} .1$

ISSN: $1983-3873$

Segundo Todorov (2006, p. 302), “é necessário dizer que naquela época Dostoiévski usava com frequência beleza e Cristo como termos intercambiáveis".

Dostoiévski, ao formular a frase "A beleza salvará o mundo", tinha plena consciência de sua importância no romance, pois Cristo, na concepção de Dostoiévski, foi o único ser capaz de colocar em prática o mais importante mandamento: amar o seu próximo como a si mesmo. Por conseguinte, o mundo só teria salvação se a humanidade seguisse o exemplo de Cristo.

Destarte, o Cristo de Hans Holbein representa para Dostoiévski o verdadeiro Cristo que veio para a Terra como um homem, para sofrer como um homem e morrer como um homem. Um Cristo que não ressuscitará e que não tem o objetivo de redimir os pecados humanos, mas apenas ser um exemplo a ser seguido pela humanidade para alcançar a imortalidade após a morte.

\section{Referências:}

BAKHTIN, M. M. Problemas da poética de Dostoiévski. 4. ed. Tradução de Paulo Bezerra. Rio de Janeiro: Forense Universitária, 2008.

BERCKEN, W. V. D. Christian fiction and religious realism in novels of Dostoevsky. New York: Anthem Press, 2011.

BERKOUWER, G. C. A pessoa de Cristo. São Paulo: ASTE,1964.

CLARK, K; HOLQUIST, M. Mikhail Bakhtin. 1. ed. Tradução de J. Guinsburg. São Paulo: Perspectiva, 2008.

DOSTOIEVSKAIA, A. G. Meu marido Dostoiévski. Tradução de Zóia Prestes. Rio de Janeiro: Mauad, 1999.

DOSTOIÉVSKI, F. M. O idiota. Tradução de Paulo Bezerra. São Paulo: Editora 34, 2002.

DOSTOIÉVSKI, F. M. Dostoiévski - correspondências (1838-1880). Tradução de Roberto Frizero. Porto Alegre: 8Inverso, 2009.

FRANK, J. Dostoiévski 1860 a 1865 - os efeitos da libertação. São Paulo: Edusp, 2002.

FRANK, J. Dostoiévski 1865 a 1871 - os anos milagrosos. São Paulo: Edusp, 2003.

FRANK, J. Dostoiévski 1871 a 1881 - o manto do profeta. São Paulo: Edusp, 2008.

GROSSMAN, N. L. Dostoiévski artista. Tradução de Boris Schnaiderman. Rio de janeiro: 


\section{Revista do SELL}

v. $4, n^{\circ} .1$

ISSN: $1983-3873$

Civilização Brasileira, 1967.

KRISTEVA, J. Sol negro, depressão e melancolia. In: KRISTEVA, Julia. O Cristo morto de Holbein. Rio de Janeiro: Rocco,1989, p. 102-129.

LOTMAN, I. A estrutura do texto artístico. Lisboa: Estampa, 1978.

TODOROV, T. A beleza salvará o mundo. In: TODOROV, Tzvetan. Viver com o absoluto. Rio de Janeiro: Difel, 2006, p. 251-326.

USPÊNSKI, B. Semiótica Russa. In: SCHNAIDERMAN, Boris. Elementos estruturais comuns às diferentes formas de arte - princípios gerais de organização da obra em pintura e literatura. São Paulo: Perspectiva, 1979, p. 163-218.

VOINOVA, N.; STARESTS, S.; VERKHUCHA, V.; ZDITOVETSKI, A. Dicionário RussoPortuguês. 2. ed. Lisboa: Ulmeiro, 2003.

WILLIAMS, R. Dostoevsky: language, faith and fiction. Texas: Baylor University Press Waco, 2008. 